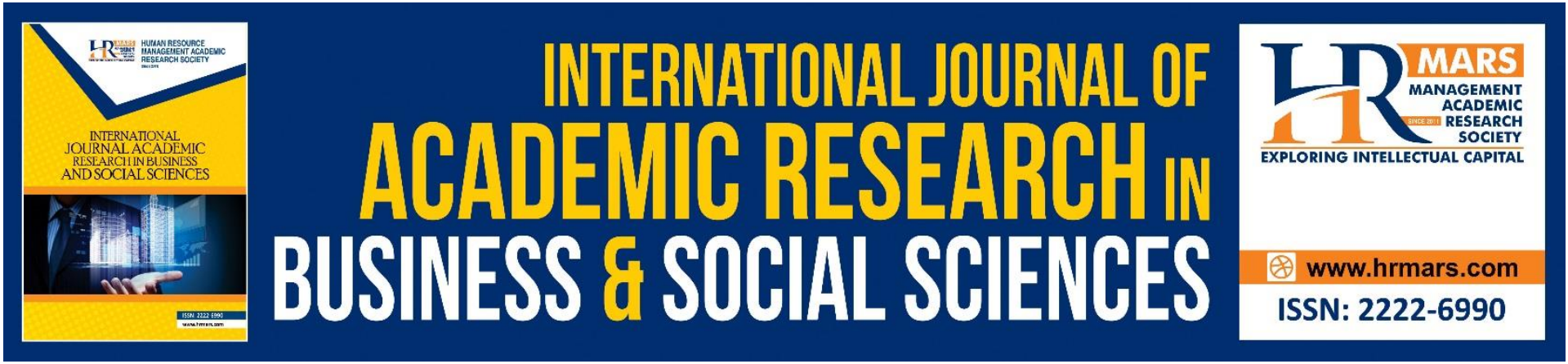

\title{
Debt Burden and Infrastructural Development in Nigeria
}

\author{
Aladejana, S. Aliu, Idowu Adeniyi, Okeowo, Oluwalana, Feyisayo Abosede, \\ John Adejare, Alabi
}

To Link this Article: http://dx.doi.org/10.6007/IJARBSS/v11-i1/8518

DOI:10.6007/IJARBSS/v11-i1/8518

Received: 19 November 2020, Revised: 10 December 2020, Accepted: 24 December 2021

Published Online: 20 January 2021

In-Text Citation: (Aladejana et al., 2021)

To Cite this Article: Aladejana, S. A., Okeowo, I. A., Oluwalana, F. A., \& Alabi, J. A. (2021). Debt Burden and Infrastructural Development in Nigeria. International Journal Academic Research in Business and Social Sciences, 11(1), 419-432.

Copyright: (C) 2021 The Author(s)

Published by Human Resource Management Academic Research Society (www.hrmars.com)

This article is published under the Creative Commons Attribution (CC BY 4.0) license. Anyone may reproduce, distribute, translate and create derivative works of this article (for both commercial and non-commercial purposes), subject to full attribution to the original publication and authors. The full terms of this license may be seen

at: http://creativecommons.org/licences/by/4.0/legalcode

Vol. 11, No. 1, 2021, Pg. 419 - 432

http://hrmars.com/index.php/pages/detail/IJARBSS

JOURNAL HOMEPAGE

Full Terms \& Conditions of access and use can be found at http://hrmars.com/index.php/pages/detail/publication-ethics 


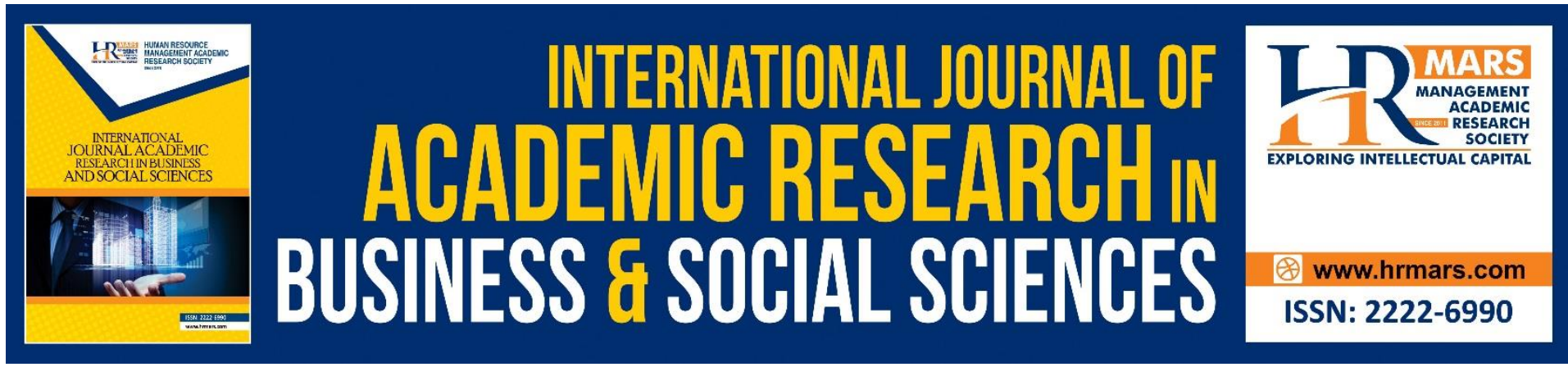

\title{
Debt Burden and Infrastructural Development in Nigeria
}

\author{
Aladejana, S. Aliu' ${ }^{1}$, Idowu Adeniyi, Okeowo² PhD
}

Department of Economics Samuel Adegboyega University, Edo State, Nigeria

Email: aladejana26@gmail.com,okeowo4hope@yahoo.com

\section{Oluwalana, Feyisayo Abosede ${ }^{3}$}

Postgraduate students, Department of Economics, Federal University Oye Ekiti, Ekiti State, Nigeria.

Email: feyidada79@gmail.com

\section{John Adejare, Alabi ${ }^{4}$}

Department of Marketing Faculty of Communication \& Management Studies

Ibarapa Polytechnic, Eruwa, Oyo State, Nigeria

Email: jarealabi2015@gmail.com

\begin{abstract}
This study evaluates debt burden, implications for infrastructural development in Nigeria for the period 1986-2019. The study embraced annual time-series data and employed the Fully Modified Ordinary Least Squares (FMOLS) estimation techniques to examine the relationship of the variables. The findings revealed that both current and lagged coefficients show a positive and significant relationship between domestic debt and infrastructural development; while the current and lagged coefficient of external debt shows a negative relationship with infrastructural development and not statistically significant during the study period. The implication of the findings is that increases in domestic debt of the federal government leads to an increase in Infrastructural development (at the short run) while federal government external debt hitherto has not resulted to any improvement in infrastructural development. Finally, Granger Causality test confirmed both uni and bi-directional relationship in the long run. The study, therefore, concluded that the external debt has not contributed significantly in the development of Nigerian's infrastructure and that the huge external debt profile of Nigeria even before the debt forgiveness of 2005/2006 to date is not justifiable and is uncalled for. It suggested that external loans should be restricted to specified identifiable infrastructural or productive projects.
\end{abstract}

Keywords: Debt burden, External Debt, Domestic Debt, Federal Government Capital Expenditure, Infrastructural Development. 


\section{Introduction}

It is a globally acknowledged fact and that most developing countries are faced with the scarcity of funds to finance major infrastructure projects in their countries. Such, they usually have to seek for borrowing funds (both external and domestic sources) which had always served as veritable financial platforms for many developing countries of the world in running their economies, on the condition of judicious use of loans for the intended projects. Borrowing creates debt and debt either from multilateral, bilateral, commercial and others sources, is the aggregate of all claims against the government held by the private sector of the economy or by foreigners, whether interest bearing or not less, any claim held by the government against private sectors and foreigners (Oyejide, Soyede and Kayode, 1985). According to African heritage policy brief 2018, shows that in 2017 Nigeria's debt burden from multilateral borrowing accounted for $47 \%$ of total debt, bilateral accounted for $18 \%$, commercial accounted for $26 \%$, and others sources accounted for $9 \%$ respectively.

Technically, debt serves as barriers to economic growth and welfare in most parts of the world. Since accumulating debts for the developing countries is situation they must leave with to achieve enhanced infrastructural facilities, most development economist are now advocating for "favourable debts". A Favourable debt is one whose the capital acquired has the potentials of high leftover after deducting the cost of loan. In this situation, the debts will be financing economic growth, increasing the infrastructural capacity and expanding output of the borrowing country (Pattilo, Ricci, \& Poirson, 2001). The term infrastructural development on the other hand is used to denote a state of improvement in the general status of the basic physical and organizational structures and facilities such as buildings, roads, and power supplies needed for the operation of a society or enterprise. Hence, these basic physical and organizational structures and facilities as already exemplified are referred to as infrastructures. Thus, infrastructural development include the provision, construction, improvement and rehabilitation of capital and productive projects like roads, airports, hospitals, education and research institutes, power development, human resources development, improved security, among others, in consonance with international standards. In sub-Saharan Africa countries, financing developmental plans are heavily tied on foreign loans, a typical example is the $1^{\text {st }}$ to $3^{\text {rd }}$ developmental plans of Nigeria (Jacob 2004). It is as a result of this and other luxury-seeking attitude of leaders in these countries that have made the countries to have a heap of external debt to a level that it is unsustainable, as they never propel the needed economic growth that could finance the repayment or to service them.

Economists believe that borrowing is healthy for the infrastructural development and may help to maintain economic growth and development, but reverse is the case in Nigeria. Unfortunately, the realities on grand including the required infrastructure and the debt accumulated between 2006 till date did not show any correlation we observed. Moreover, it's been so long now since Nigeria celebrated the repayment of Paris Club debt. The narrative back then was that paying the debt will free up cash that will be channeled towards capital expenditure and then usher in the economic boom we have craved for decades. Even the present administration since 2015 claims that it has no choice than to borrowing more to finance deficit budget, instead what we got was a higher spending on recurrent expenditure, limited capital expenditure and a lot of stolen wealth, we are somewhat back full circle.

However, statistical evidence has shown that Nigeria total domestic debt astronomically rose from Nigeria 9.6 trillion naira in 2015 to 10.6 trillion naira, 15.93 trillion naira, 16.7 trillion naira, and 18.83 trillion naira in 2016, 2017, 2018 and 2019 with GDP ratio of $12.8 \%$ in 2015 and $12.9 \%, 13.35 \%, 13.38 \%$, and $14.01 \%$ respectively. While that of external debt increase 
from $\$ 10.72$ billion in 2015 to $\$ 15.35$ billion, $\$ 18.91$ billion, $\$ 22.07$ billion and $\$ 27$ billion in $2016,2017,2018$ and 2019 with ratio to GDP are $20.33 \%, 23.41 \%, 25.34 \%, 27.26 \%$ and $29.78 \%$ respectively. Moreover, heavily indebted poor countries have higher rates of infant mortality, disease, illiteracy, and malnutrition than other countries in the developing world, according to the United Nations Development Programme (UNDP 1998). The African Development Bank in its African Economic Outlook (2019) stated that about 50\% of the country's revenue is now spending on external debt servicing. Concretely speaking, 2.45 trillion naira was allocated to debt servicing in the 2020 budget out of 10.33 trillion naira total expenditure. In spite of yearly increase in both internal and external borrowing, yet, there is no evidence that the borrowed funds are being properly utilized in bringing about the kind of radical development in infrastructure needed to measure up with their $1^{\text {st }}$ world counterparts.

\section{Statement of the Problem}

Statement of the Problem Countries of the world in general and developing countries in particular (Nigeria inclusive) resort to borrowings, ideally, to bridge up any resource availability gap in tackling pressing and essential economic needs that tend to improve on the welfare and standard of living of the citizenry. Consequently, Sulaiman and Azeez (2012) argued that no government is an island on its own and it would require aid so as to perform efficiently and effectively. In Nigeria's case, the lopsidedness and perceived inequity in the distribution of infrastructure remains one of the drivers of regional agitations and political instability. Despite the excessive increase in borrowing over decade, levels of access to basic physical infrastructure such as clean water and improved sanitation, electricity and (paved) roads in Nigeria are inadequate given its income levels and its rapidly growing population and this has considerably limits efforts towards achieving inclusive growth, sustainable development, and poverty reduction. In a similar vein, Nigeria's 2017 Economic Recovery \& Growth Plan (ERGP) points to 'deplorable infrastructure, alongside corruption and mismanagement of public finances as one of the main factors that 'seriously undermined' economic performance in the past.

Despite some progress over the past decades, Nigeria's infrastructure access levels are benchmarked against access levels of other lower middle-income economies in African as well as lower middle-income economies globally, specifically Pakistan, India and Indonesia. Looking to the future, rising incomes and rapid population growth are bound to significantly increase future demand for infrastructure in Nigeria. Over the next 23 years, Nigeria's population is expected to increase from its current estimate of 190 million people to almost 330 million, representing a more than $70 \%$ increase. On this trajectory, by 2040 , Nigeria would become the fourth most populous country in the world, behind only India, China and the United States of America. Without drastic improvements in Nigeria's basic physical infrastructure, this growth will compound the existing deficit.

On the other hand, a significant amount of research has been conducted in developed countries and emerging economies to prove and establish the relationship between external, domestic debt and economic growth nexus. Among most recent and comprehensive survey of this literature are; (Borensztelin, 1990; Amassoma, 2011; Egbetunde, 2012; Onyeiwu, 2012; Ajayi and Oke, 2012; Ejigayehu, 2013; Olasode and Babatunde, 2016; Fagboyo, 2017; Falade, Aladejana and Oluwalana, 2018 and Alagba and Eferakeya, 2019). However, the empirical evidence based on those studies is mixed and often contradictory. In part, differences in the data's, the sampling period, and methodologies adopted explain the inconclusive results. 
Moreover, Debt Burden, Implications for Infrastructural Development has not been seriously considered in the literature. Hence, this study seeks to fill the gap in the literature.

The broad objective of this study is to analyze the effects of Nigeria's Debt Burden (both external and internal) on infrastructural development. Hence, granger causality econometric techniques will be applied to tests whether debt (external and internal) granger causes infrastructural development, or whether the causality runs from infrastructural development to debt (external or internal), or if there is existence of bi-directional causality between the variables.

The rest of the article is structured as follows. Section 2 provides an overview of trends in Nigeria's Debt Burden (both external and internal) on infrastructural development indicators while section 3 discussion the specifies methodology used in study and data sources. Section 4 provides empirical findings, and section 5 presents Summary and Conclusion.

\section{Nigeria's Debt Burden and Infrastructural Development Trends}

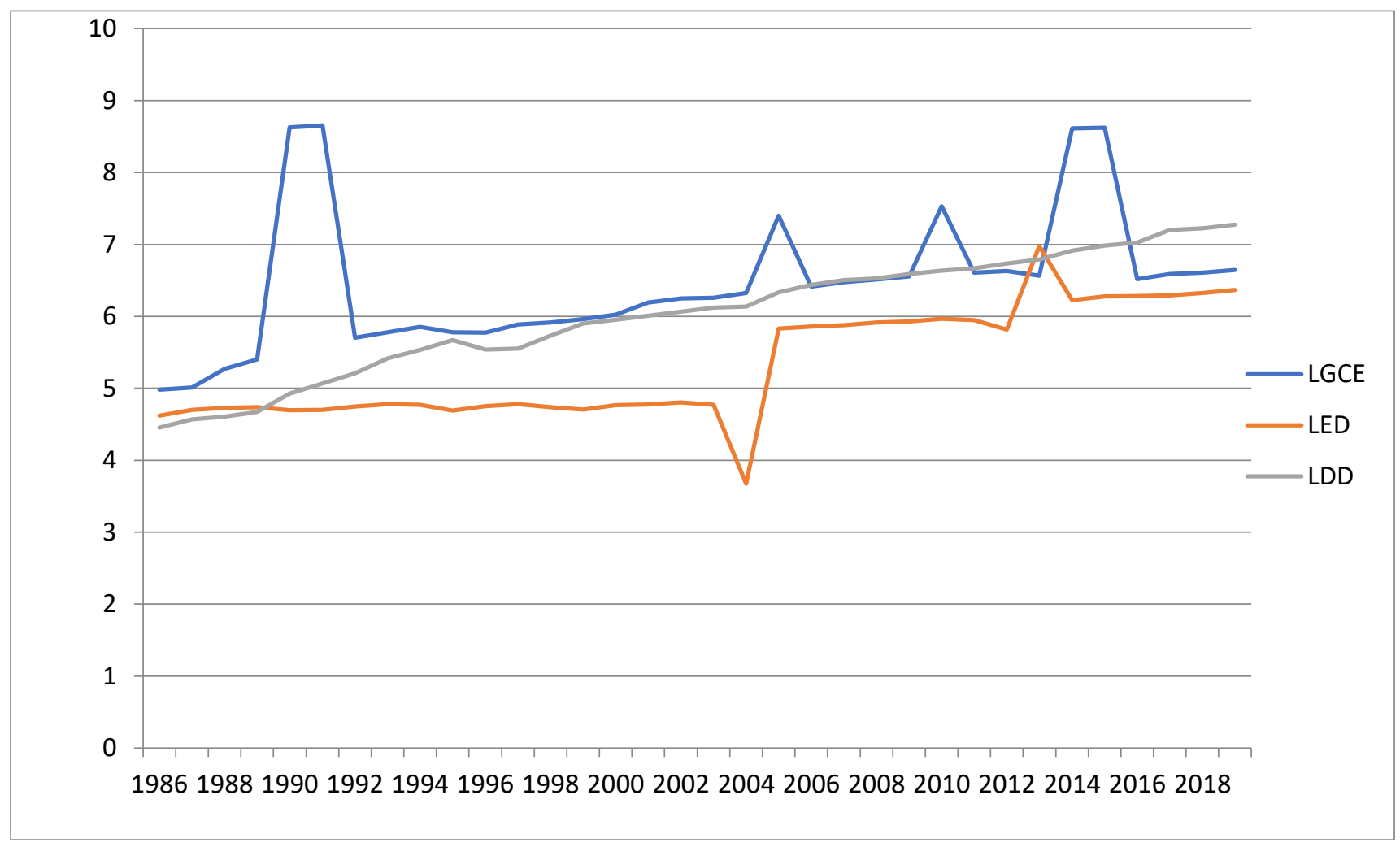

Figure 1: Trend of federal Government Capital Expenditure, External debt and Domestic debt in Nigeria, 1986-2019.

Source: Data, CBN, NBS and IFS, 2019

The graph above indicates that federal government capital expenditure (LGCE) exhibited an upward trend over the study period whereas External debt (LED) and Domestic debt (LDD) which captures debt burden trended positively with the Nigeria's Federal Government Capital Expenditure (a proxy for Infrastructural Development) between 1986 to 2019. Both the external debt (LED) and domestic debt (LDD) shows upward movement from 1998 to 2003 after which the external debt (LED) decreased due to the debt relief granted Nigeria between October 2005 and April, 2006 by the bilateral official creditors (Paris Club), and this restored investor confidence on the economy. Domestic debt (LDD) however has been on increases 
without corresponding increases in infrastructural development as result of poor lending and inefficient loan utilization, and poor debt management practices in Nigeria. As show in the graph, reduction in the external debt burden has been accompanied by a significant increase in the Government Capital Expenditure (a proxy for Infrastructural Development) from 2012 to 2015.

\section{Data and Methods}

This study will apply fully modified ordinary least square (FM-OLS) analysis technique in order to investigate debt burden, implications for infrastructural development in Nigeria. This will enable us to induce flexibility by contributing the dynamics significance of the variables on economic growth in a unified manner for the period of the study. The method used in this study is a technique for fitting the sum when the squared vertical deviation of point from the line, that is the overall discrepancy between the variables in the model. This means that the sum of all the residual would be a measure of all overall discrepancy of the point from the line. Applying the use of FM-OLS is very significant such that the outcome of the residual ui is normally distributed in the model when the explanations for the behavior of the variables are offered. The FM-OLS is also to establish the coefficients or the type of relationship that exist and the degree of the relationship in the model in Nigeria for the period 1986-2019.

Furthermore, there is a need for pre-test (stationary and co-integrated) in the model to examine the causal relationship between the variables. The stationary test and co-integration testis used to show the short and long run equilibrium relationship respectively; between the variables using Augmented Dickey Fully (ADF) test and Johansen co-integration test. The short and long run dynamic in the co-integration series is require in the model.

This study adopted Amaefule and Umeaka, (2016), with little modification.

The study model which is given as:

$Y=\beta_{0}+\beta_{1} X_{1}+\beta_{2} X_{2}+\mathrm{U}$.

Where:

$Y=$ Federal Government Capital Expenditure (a proxy for Infrastructural Development)

$X_{1}=$ Federal Government's External Debt

$X_{2}=$ Federal Government's Domestic Debt

$\beta_{1} \& \beta_{2}=$ the coefficient of the independent variables

$\mathrm{U}=$ Error term.

The model adopted for the study used two (2) variables as independent variables on federal government capital expenditure but to suit our topic and also to add to empirical literature for further research. The following variable is added to the model and this mathematically written as: $G C E=f(E D, D D, C S D, E R I N F)$

$\mathrm{GCE}=\mathrm{F}(\mathrm{ED}, \mathrm{DD}, \mathrm{CSD}, \mathrm{ER})$

$\mathrm{GCE}=$ Government Capital Expenditure

$\mathrm{ED}=$ External Debt

$\mathrm{DD}=$ Domestic Debt

CSD $=$ Cost of servicing debt

$\mathrm{ER}=$ Official exchange rate

INF= Inflation rate.

On the a priori, we expect; $\beta_{1}>0, \beta_{2}>0, \beta_{3}>0, \beta_{4}>0$

Econometrically, equation (ii) is written as:

$\ln G C E_{t}=\beta_{0}+\beta_{1} \ln E D_{t}+\beta_{2} \ln D D_{t}+\beta_{3} \ln C S D_{t}+\beta_{4} E R_{t}+\beta_{5} \mathrm{INF}+U_{1}$ 
Equation (iii) shall be estimated in the course of this study. Where: $\beta_{1}$ to $\beta_{4}=$ the parameters to be estimated and $U_{1}=$ the error term. Follow: $\beta_{1}, \beta_{2}, \beta_{3}$ and $\beta_{4}>0$

\section{Descriptive Statistics}

The result of the descriptive statistics is shown below.

Table 1: Descriptive Statistics Result

\begin{tabular}{|l|c|c|c|c|c|c|}
\hline & LGCE & ER & INF & LCSD & LDD & LED \\
\hline Mean & 14.89380 & 106.9997 & 19.96706 & 11.30706 & 13.88067 & 12.24494 \\
\hline Median & 14.66543 & 119.5650 & 12.00000 & 11.39981 & 14.03264 & 11.004931 \\
\hline Maximum & 19.92506 & 380.7200 & 76.80000 & 12.94849 & 16.75096 & 16.06153 \\
\hline Minimum & 11.46919 & 2.020000 & 0.200000 & 9.233090 & 10.25556 & 8.458222 \\
\hline Std. Dev. & 2.24886 & 94.44084 & 18.70699 & 1.230949 & 1.905666 & 1.790907 \\
\hline Skewness & 1.019849 & 1.053661 & 1.717522 & -0.371266 & -0.339028 & $0 . .240423$ \\
\hline Kurtosis & 3.570714 & 4.194465 & 4.770741 & 1.895232 & 2.079908 & 1.998447 \\
\hline Jarque-Bera & 6.3555286 & 8.312362 & 21.15799 & 2.510146 & 1.850631 & 1.748622 \\
\hline Probability & 0.041684 & 0.015667 & 0.000025 & 0.285055 & 0.396406 & 0.417149 \\
\hline Sum & 506.3892 & 3637.990 & 678.8800 & 384.4401 & 471.9428 & 416.3278 \\
\hline Sum Sq.Dev. & 166.4522 & 294329.4 & 11548.39 & 50.00280 & 119.8415 & 105.8425 \\
\hline Observations & 34 & 34 & 34 & 34 & 34 & 34 \\
\hline
\end{tabular}

Source: Author's computation, 2020

Table 1 shows the summary of descriptive statistics of the variables included in the model. It shows the existence of wide variations in the variables as depicted by the mean values. The analysis shows that the standard deviations of the official exchange rate and inflation rate are high. All the distributions in the analysis are positively skewed with the exception of cost of servicing debt (LCSD) and domestic debt (LDD) that are negatively skewed. Variables with value of kurtosis less than three are called platy kurtic (fat or short-tailed) and cost of servicing debt (LCSD), domestic debt (LDD) and external debt (LED), variable qualified for this during the study period. On the other hand, variables whose kurtosis value is greater than three are called leptokurtic (slim or long tailed) and official exchange rate (ER) and inflation rate (INF) variables qualified for this during the period of the study. Jarque-Bera statistic shows that the residuals of most of the variables are not normally distributed. This shows that some operations are required to normalize the time series data.

\section{Test of Stationarity}

The study first investigated the time series properties of the data. It has been established in literature that most time series variables are not stationary, hence the need to establish stationarity before using them in a model to avoid spurious regression. A series is said to be stationary if its mean and variance are constant over time and the value of the covariance between the two-time periods depends only on the distance or lag between the two-time periods and not the actual time at which the covariance are computed (Gujarati, 2003). A nonstationary variable can be made stationary if differenced appropriately. The appropriate number of differencing is called the order of integration. The study therefore employed the Augmented Dickey-Fuller (ADF) unit root test to check the stationarity properties of the data. The essence of the ADF is to test the null hypothesis of unit root or non-stationary stochastic process. To reject this, the ADF statistic must be more negative than the critical value at $5 \%$ significance level. 
Table2 below presents the results of test statistics for the levels and first differences of the stochastic time series data for the period of 1986 to 2019.

Table 2. Unit Root Test (ADF Test)

\begin{tabular}{|l|c|c|c|c|c|c|}
\hline Variables & \multicolumn{3}{|c|}{ @Level } & \multicolumn{3}{c|}{ First difference } \\
\hline & t-start & $5 \%$ & Prob** & t-stat & $5 \%$ & Prob** $^{* *}$ \\
\hline ER & 2.157991 & -2.954021 & 0.9999 & -3.429867 & -2.957110 & 0.0172 \\
\hline INF & -2.745072 & -2.954021 & 0.0774 & -4.985543 & -2.967767 & 0.0004 \\
\hline LCSD & -1.269080 & -2.954021 & 0.6320 & -4.164206 & -2.957110 & 0.0027 \\
\hline LDD & -.1 .712774 & -2.954021 & 0.4157 & -2.754583 & -1.951687 & 0.0075 \\
\hline LED & -0.916611 & -2.957110 & 0.7698 & -8.809477 & -2.957110 & 0.0000 \\
\hline LGCE & -3.559225 & -2.954021 & 0.0124 & -6.125060 & -1.952066 & 0.0000 \\
\hline
\end{tabular}

\section{Source: Author's computation, 2020}

From the Table 2 above, the result reveals that all the variables in the model are nonstationary at level, at $5 \%$ level of significance except LCGE. Based on this we difference the variables to see their outcome. Similarly, tables 2 above, indicates that all the variables are integrated of same order one i.e. I (1). In other words the result shows that ER, INF, LCSD, LDD, LED and LGCE are stationary at $5 \%$ level of significance. And so, having established stationarity among the variables, we proceed to co-integration with a view to determining the number of co-integrating equation in the model.

Table 3: Unrestricted Cointegration Rank (Trace)

\begin{tabular}{|l|l|l|l|l|}
\hline $\begin{array}{l}\text { Hypothesized } \\
\text { No. of CE(s) }\end{array}$ & Eigenvalue & $\begin{array}{l}\text { Trace } \\
\text { Stat. }\end{array}$ & $\begin{array}{l}0.05 \\
\text { C.V }\end{array}$ & Prob** \\
\hline None* & 0.860467 & 139.0276 & 95.75366 & 0.0000 \\
\hline At most1* & 0.672892 & 76.00519 & 69.81889 & 0.0147 \\
\hline At most2 & 0.486701 & 40.24635 & 47.85613 & 0.2138 \\
\hline At most3 & 0.338108 & 18.90563 & 29.79707 & 0.4997 \\
\hline At most4 & 0.162353 & 5.700755 & 15.49471 & 0.7306 \\
\hline At most5 & 0.000989 & 0.031673 & 3.841466 & 0.8587 \\
\hline
\end{tabular}

Source: Author's computation, 2020

From the unrestricted Cointegration rank (Trace) result above, the null hypothesis that there is no Cointegration was rejected at 5 percent and the alternative hypothesis that there is Cointegration among the variables used in the study at 5 percent was accepted. Hence, the exists a long run relationship among the variables employed for the study.

Table 4 Unrestricted Cointegration Rank (Maximum Eigenvalue)

\begin{tabular}{|l|l|l|l|l|}
\hline $\begin{array}{l}\text { Hypothesized } \\
\text { No. of CE(s) }\end{array}$ & Eigenvalue & $\begin{array}{l}\text { Max-Eigen } \\
\text { Statistic }\end{array}$ & $\begin{array}{l}0.05 \\
\text { C.V }\end{array}$ & Prob** \\
\hline None* & 0.860467 & 63.02243 & 40.07757 & 0.0000 \\
\hline At most1* & 0.672892 & 35.75883 & 33.87687 & 0.0295 \\
\hline At most2 & 0.486701 & 21.34072 & 27.58434 & 0.2562 \\
\hline At most3 & 0.338108 & 13.20488 & 21.13162 & 0.4336 \\
\hline At most4 & 0.162353 & 5.669082 & 14.26460 & 0.6560 \\
\hline At most5 & 0.000989 & 0.031673 & 3.841466 & 0.8587 \\
\hline
\end{tabular}

Source: Author's computation, 2020 
From the Unrestricted Cointegration rank (Max-Eigen value) result above, the null hypothesis that there is no Cointegration was rejected at 5 percent and the alternative hypothesis that there is Cointegration among the variables used in the study at 5 percent was accepted. Hence, there exists a long run relationship among the variables employed for this study.

Table 5 Full Modify Ordinary Least Square Results

\begin{tabular}{|l|l|l|l|l|}
\hline Dependent Variable: D(LGCE) & Coefficient & Std. Error & t-Statistic & Prob. \\
\hline Variable & 0.451511 & 0.386399 & 1.168511 & 0.2571 \\
\hline$D$ & -0.019961 & 0.015342 & -1.301010 & 0.2088 \\
\hline$D($ INF) & -0.060312 & 0.021640 & -2.787048 & 0.0118 \\
\hline$D($ LCSD) & -1.569878 & 1.113583 & -1.409755 & 0.1748 \\
\hline$D(D($ LDD)) & 4.303213 & 1.504146 & 2.860901 & 0.0100 \\
\hline$D($ LED) & -0.832249 & 0.380756 & -2.185779 & 0.0416 \\
\hline$D(E R(-1))$ & 0.019588 & 0.014478 & 1.352890 & 0.1920 \\
\hline$D($ INF(-1)) & -0.031947 & 0.018275 & -1.748126 & 0.0966 \\
\hline$D($ LCSD(-1)) & -0.120235 & 1.340369 & -0.08970 & 0.9295 \\
\hline$D(D(L D D(-1)))$ & 3.638971 & 1.524324 & 2.387268 & 0.0275 \\
\hline$D($ LED(-1)) & -0.304789 & 0.453352 & -0.672299 & 0.5095 \\
\hline ECM(-1) & -0.658529 & 0.201177 & -3.273376 & 0.0040 \\
\hline$R-S q u a r d ~$ & & & \\
\hline
\end{tabular}

R-squared 0.711594

Adjusted R-squared 0.544622

Durbin-Watson stat 1.529872

F-statistic 4.261757

Prob (F-statistic) 0.002821

\section{Source: Author's computation, 2020}

In Table 5 above, the goodness of fit statistics was impressive with adjusted $R^{2}$ value of 0.545 which was highly significant and it indicated that over $54 \%$ of the systematic variations in government capital expenditure (LGCE) were captured by the selected variables in the shortrun. As shown by the F-statistics, the model was statistically significant at 5\%.The ECM had the expected negative sign and was significant at the $5 \%$ level. It was the significant and expected sign that indicated that long run equilibrium would always be achieved even though there was a short run deviation. However, since the coefficient was less than 1 , it suggested that an adjustment to lung run equilibrium could oscillate over time.

From the results in the table 5 , the current and lagged coefficients of the official exchange rate were observed; $D(E R)(-0.019961, P=0.2088), D(E R)_{(-1)}(0.019588, p=0.1920)$ and $D(E R)$ shows negative and not significant effect on government capital expenditure (proxy to infrastructural development) while lag1 $D(E R(-1)$ shows positive sign but not significant as well. The current and lagged coefficients of inflation rate (INF) were observed; D (INF) ($0.060312, P=0.0118$ ) and $D(I N F(-1)-0.031947, P=0.0966)$. The short run effect of inflation rate on government expenditure capital expenditure (proxy to infrastructural development) showed that the current and lag1 coefficients of government expenditure (proxy to infrastructural development) were significant at $5 \%$ level respectively. The effects in the shortrun indicated that inflation rate (INF) has an immediate significant decreasing effect on infrastructural development during the study period. 
The current and lagged coefficients of cost of servicing debt (LCSD) were observed; D (LCSD) $(-1.569878, P=0.1748)$ and $D($ LCSD) $(-1)(-0.120235, P=0.9295)$. The effects in the short-run indicated that both coefficient sign were positive and not significant at $5 \%$ level. The results also revealed the short-run coefficients of domestic debt (LDD) $(4.303213, p=0.0100)$ while $D$ (D (LDD $(-1) \quad 3.638971, P=0.0275)$. The results indicated that both current and lagged coefficients have a positive and significant effect on infrastructural development in Nigeria during the study period. This result is in line with Alagba and Ugwu, (2017), Amaefule and Umeaka, (2016), Alagba and Eferakeya, (2019), Tamunomim, (2014), Ozurumba and Kanu, (2014) and Didia and Ayokunle, (2020) that domestic debt has positive relationship with infrastructural development in Nigeria. The result also affirms the findings of the previous studies that domestic debt appears to be more benefit in term of infrastructural development in Nigeria. However, the result runs contrary to the findings of the study by Onyeiwu (2012) and Adofu and Abula (2010). Finally, the current and lagged coefficient of external debt (LED) were also observed; $D\left(\right.$ LED) $(-0.832249, p=0.0416)$ and $D\left(\operatorname{LED}_{(-1)}-0.304789, p=0.5095\right)$. This suggests that external debt (current (D (LED)) has a negative related with infrastructural development but statistically significant at $5 \%$ level during the study period. With $5 \%$ level, lagged coefficient of external debt shows a negative and not statistically significant in the model during the study period in Nigeria and the result is in line with Fagboyo, (2017), Ezeabasili, Isu and Mojekwu, (2011), and Ogunmuyiwa, (2011) in Nigeria. 
INTERNATIONAL JOURNAL OF ACADEMIC RESEARCH IN BUSINESS AND SOCIAL SCIENCES Vol. 11, No. 1, 2021, E-ISSN: 2222-6990 @ 2021 HRMARS

\section{Granger Causality Test}

\begin{tabular}{|l|c|c|c|c|}
\hline Null Hypothesis & Lag & Obs & F-Statistic & Prob. \\
\hline ER does not Granger cause LGCE & 2 & 32 & 1.41517 & 0.2603 \\
LGCE does not Granger cause ER & & & 1.05839 & 0.3610 \\
\hline INF does not Granger cause LGCE & 2 & 32 & 1.77035 & 0.1895 \\
LGCE does not Granger cause INF & & & 0.06426 & 0.9632 \\
\hline LCSD does not Granger cause LGCE & 2 & 32 & 0.22570 & 0.7994 \\
LGCE does not Granger cause LCSD & & & 0.03756 & 0.9632 \\
\hline LDD does not Granger cause LGCE & 2 & 32 & 0.90823 & 0.4152 \\
LGCE does not Granger cause LDD & & & 1.54341 & 0.2319 \\
\hline LED does not Granger cause LGCE & 2 & 32 & 2.49066 & 0.1017 \\
LGCE does not Granger cause LED & & & 0.19176 & 0.8266 \\
\hline INF does not Granger cause ER & 2 & 32 & 0.28714 & 0.7527 \\
ER does not Granger cause INF & & & 3.15074 & 0.0589 \\
\hline LCSD does not Granger cause ER & 2 & 32 & 1.67207 & 0.2067 \\
ER does not Granger cause LCSD & & & 0.01335 & 0.9867 \\
\hline LDD does not Granger cause ER & 2 & 32 & 1.53529 & 0.2336 \\
ER does not Granger cause LDD & & & 0.35384 & 0.7052 \\
\hline LED does not Granger cause ER & 2 & 32 & 0.61529 & 0.5479 \\
ER does not Granger cause LED & & & 2.79003 & 0.0792 \\
\hline LCSD does not Granger cause INF & 2 & 32 & 5.66302 & 0.0088 \\
INF does not Granger cause LCSD & & & 0.37239 & 0.6926 \\
\hline LDD does not Granger cause INF & 2 & 32 & 4.87699 & 0.0156 \\
INF does not Granger cause LDD & & & 0.48961 & 0.6182 \\
\hline LED does not Granger cause INF & 2 & 32 & 1.13457 & 0.3364 \\
INF does not Granger cause LED & & & 0.67488 & 0.5176 \\
\hline LDD does not Granger cause LCSD & 2 & 32 & 0.71857 & 0.4965 \\
LCSD does not Granger cause LDD & & & 0.54810 & 0.5843 \\
\hline LED does not Granger cause LCSD & 2 & 32 & 0.56404 & 0.0007 \\
LCSD does not Granger cause LED & & & 1.93725 & 0.1636 \\
\hline LED does not Granger cause LDD & & & & 0.0307 \\
\hline LDD does not Granger cause LED & & & & \\
\hline
\end{tabular}

\section{Source: Author's computation, 2020}

The Table above shows that causal relationship between LGCE (Government Capital Expenditure), ER (Official exchange rate), INF (Inflation rate), LED (External debt), LDD (Domestic debt), and LCSD (Cost of servicing debt) in Nigeria during the period of 1986-2019. The result revealed that no causal relationship existed between; ER (Official exchange rate) and LGCE (Government capital expenditure), INF (Inflation rate) and LGCE (Government capital expenditure), LCSD (Cost of servicing debt) and LGCE (Government capital expenditure), LDD (Domestic debt) and LGCE (Government capital expenditure), LED (External debt) and LGCE (Government capital expenditure), LCSD (Cost of servicing debt) and ER (Official exchange rate), LDD (Domestic debt) and ER (Official exchange rate), LED (External debt) and INF (Inflation rate), LDD (Domestic debt), and LCSD (Cost of servicing debt), and LED (External debt) and LDD (Domestic debt). This tends to support the neutrality hypothesis. There is a Uni-directional causal relationship between official exchange rate (ER) and inflation rate (INF), official exchange rate (ER) and external debt (LED), cost of servicing debt (LCSD) and 
inflation rate (INF) and Domestic debt (LDD) and inflation rate (INF) without feedback mechanism. Finally, the study however established a bi-directional relationship between external debts (LED) and cost of servicing debt (LCSD), cost of servicing debt and external debt with a feedback mechanism of $5 \%$ at critical level in the estimated model.

\section{Conclusion}

From the results of the statistical analysis as already discussed, the study affirms that:

i. External debt of Nigeria has not been instrumental in enhancing the development of Nigeria's physical infrastructure and increase in the level of debt servicing to the various creditors to the economy would reduce the level of infrastructural development in Nigeria. Thus, the huge external debt profile of Nigeria even before the debt forgiveness of 2005/2006till now is not justifiable and uncalled for.

ii. It is also ascertained that domestic debt is better-off and superior to external debt in terms of overall growth and infrastructural development, and that domestic debt accumulation contributes significantly to the development process of the nation as it leads to a rise in aggregate demand, output and employment generations.

iii. In the long run, both external and domestic borrowings are adverse to infrastructural development in Nigeria which is occasioned by inefficient loan utilization, poor debt management practices and insincerity and corrupt dispositions of government functionaries.

\section{Recommendation}

In the face of the findings and conclusion above, the following recommendations are proffered to the government:

i. The modalities of incurring external debt and their application should be technically and tactically analyzed prior to accessing the debt, as external debts in the first year of receipts tends to have a negative impact on the Nigerian economy.

ii. Although, External debts are meant to boost the economic growth and development of the debtor country and improve the standard of living of the citizenry, as such Nigerian government should ensure that debts incurred are channel towards the specific and identified infrastructural productive projects and not just for solving short run problems.

iii. In line with this, the Debt Management Office should strengthen their plans and ensure that external loans be taken only if needed in critical capital areas that must be strictly monitored.

iv. Nigeria should use her accumulated external foreign reserves instead of incurring more external debts, as this will ensure increase in real economic growth and reduce capital flights through repayments of debts to external sources.

\section{References}

Adofu, I., \& Abula, M. (2010). Domestic debt and the Nigerian economy. Current Research Journal of Economic Theory, 2(1), 22-26.

Ajayi, L. B., \& Oke, M. O. (2012).Effect of external debt on economic growth and development of Nigeria. International Journal of Business and Social Science, 3(12), 297-304.

Alagba, O. S., \& Eferakeya, I. (2019). Effect of public debt on economic growth in Nigeria: An empirical analysis 1981-2018.International Journal of Business and Economic Development, 7(2), 10-17. 
Amaefule, L. I., \& Umeaka, E. C. (2016). Effects of government's borrowing on Nigerian infrastructural development, Euro-Asia Journal of Economics and Finance, 4(4), 93112.

Amassoma, D. (2011). External debt, internal debt and economic growth bound in Nigeria using a causality approach. Current Research Journal of Social Sciences, 3(4), 320325.

Borensztelin, E. (1990). Debt overhang, debt reduction and investment: The case of Philippine. International Monetary Fund working paper. No. WP/03/249, 1-24.

Didia, D., \& Ayokunle, P. (2020). External debt, domestic debt and economic growth: The case of Nigeria, Advances in Economics and Business 8(2), 85-94. http://www.hrpub.org DOI: 10.13189/aeb.2020.080202

Debt Management Office. (2013). Publication, federal republic of Nigeria. November, 2013.

Egbetunde, T. (2012). Public debt and economic growth in Nigeria: Evidence from granger causality. American Journal of Economics, 2(6), 101 - 106.

Ejigayehu, D. A. (2013). The effect of external debt on economic growth. Sodertorns hogskola/Department of Economics, Magisteruppsats 30hp/Varterminen 2013, Sodertoms University.

Ezeabasili, V. N., Isu, H. O., \& Mojekwu, J. N. (2011). Nigeria's external debt and economic growth: An error correction approach. International Journal of Business and Management, 6(5), 156-163.

Fagboyo, E. (2017). The impact of external debt on economic growth in Nigeria. A research work submitted to the department of economics, college of management and social sciences, Samuel Adegboyega University, Ogwa, Edo State in partial fulfillment of the requirements for the award of bachelor of sciences (B.Sc) degree in Economics.

Falade, A. O. O., Aladejana, S. A., \& Oluwalana, F. A. (2018). External debt in Nigeria: How sustainable using heavily indebted poor countries (HIPC) indicators? AAU Annals of Accounting, Educational \& Social Research, 5(2):34-43, 2018.

Gujarati, D. N. (2003). Basic econometrics. USA: McGraw-Hill.

Jacob, C. (2004). Domestic debt market in Sub-Saharan in Africa. International Monetary Fund Macroeconomic Stability, Washington.

Olasode, O. S., \& Babatunde, T. S. (2016). External debts and economic growth in Nigeria: An empirical study using autoregressive distributed Lag model. Business and Economics Journal, 7(3), 2-9.

Onyeiwu, C. (2012). Domestic debt and the growth of Nigerian economy. Research Journal of Finance and Accounting, 3(5), 45-56.

Oyejide, T., Soyede, A., \& Kayode, M.O. (1985).Nigeria and the international monetary fund, Ibadan: Heinemann Book Nigeria Ltd.

Ozurumba, B. A., \& Kanu, S. I. (2014). Domestic debts and economic growth in Nigeria (19802011). Journal of Economics and Sustainable Development, 5(1), 121-133. www.iiste.org

Pattilo, C., Ricci, L., \& Poirson, H. (2001). Non-linear impact of external debt growth. Journal of Policy Modeling 31: 272-288.

Sulaiman, L. A., \& Azeez, B. A. (2012). Effect of external debt on economic growth of Nigeria. Journal of Economics and sustainable development, 3(8), 71-79.

Tamunonimim, A. N. (2014). Domestic debt and poverty in Nigeria: An empirical time series investigation. European Journal of Accounting Auditing and Finance Research, 2(5), 3344. 
INTERNATIONAL JOURNAL OF ACADEMIC RESEARCH IN BUSINESS AND SOCIAL SCIENCES

Vol. 11, No. 1, 2021, E-ISSN: 2222-6990 @ 2021 HRMARS

United Nations Development Programme, Human Development Report 1998, Oxford University Press, New York, 1998. 